\title{
THE POSSIBILITY OF USING OF ARTIFICIAL NEURAL NETWORKS TO SUPPORTING OF INVENTORY MANAGEMENT
}

\begin{abstract}
In the paper, the analysis of the possibility of using of artificial neural networks to forecast demand level in trading company was introducted. The aim of research was to build and carry out analysis regression and prognostic models of ANN by using Statistica Neural Networks software. Finally, results of neural models were verified with historical data of the value of sales. Obtained results confirmed possibility of ANN model application as effective tool to forecasting demand level in trading company.
\end{abstract}

\section{INTRODUCTION}

Since always, the management of companies that have their own warehouses is interested of warehouse management and its associated inventory control. This is mainly related to the freezing of a large part of the working capital, precise determination of safety stock and the economic size of the order. Maintaining of inventory is often a necessary condition the functioning of the manufacturing, commercial and multiple service companies.

The level of inventories should be adapted to the expected sales. Many companies can realize sales only in a situation when you have a supply of finished products or goods (eg traditional commercial enterprises, putting them in shops or markets). There are also companies that, at the time of offering specific products, goods to potential customers, do not have them physically. This applies for example production to order or commerce. However, even in these cases it is difficult to avoid such inventories for the production in progress (first case) or the goods (in the second case - even if the orders are within 24 hours). Maintaining inventory costs in the enterprise, but also has its positive aspects. Thus, in practice, production and trade enterprises to eliminate stocks seems neither possible nor beneficial (stocks may not be present in some of the service companies). Without a doubt, however, should increase the effectiveness of management, the more that errors in inventory management can lead to a decline in such sales or inflating costs, which can have negative effects on the performance of companies[4].

Often, companies are missing a simple inventory management mechanisms. Sometimes, some companies use the simplest method of managing matériel, and thus limiting their maximum. It calculates the volume of production (by value) and it is assumed, for which the level of inventories a company can afford. Often, companies need to work so that as little as possible freezing the money (that is, having the least amount of inventory) to ensure seamless production that was always required material at the disposal

\footnotetext{
${ }^{1} \mathrm{Ph}$ D. Irena Nowotyńska, Department of Computer Engineering in Management, Rzeszow University of Technology, Rzeszow.
} 
of the production, as even the smallest purchase of raw material can not stop the entire production process, leading to downtime . On the other hand, while the accumulation of too much material could expose the company to the loss of liquidity. Appropriate to examine the demand profile and to determine on the basis of reliable estimates will reduce costs primarily stocks. Reliable forecasts allow for dynamic adjustment of inventories to market requirements, which will increase the liquidity of the company[1].

The development of computer technology, especially data processing systems, has enabled the implementation of complex mathematical methods, among which play an important role in the markets already proven developed neural network models, belonging to the methods of artificial intelligence. In recent years, sales increased sharply neural networks and their use in various fields of science. Artificial neural networks (Neural Networks) fall within the scope computer science, cybernetics, biology, medicine, mathematics and logistics.

The purpose of this paper is to show the possibility of applying of artificial intelligence methods for forecasting demand in the trading company.

\section{APPLICATION ANN TO FORECAST DEMAND LEVEL}

Artificial neural networks (ANN) are commonly used tool for solving many complex issues, including engineering and logistics ones $[2-4,6]$. The neural networks are special modeling technique, which enables mapping complex functions, especially in logistics. The neural networks enable creating models without clear establishing the hypothesis about the nature the relationship between input data and predicted results [7]. When creating an optimal neural network model, it is necessary to select properly input variables, which affect output variables. Accounting for less significant parameters leads to neural network structure growth and increases the learning set count demands. However, omitting the parameters, which significantly affect the output variables, on the network input may deteriorate the quality of neural network response. When choosing ANN structure, the automatic network designer from the ST Neural Networks package may be helpful. This designer conducts the experiments automatically with various network configurations, repeating the learning process for each examined structure and choosing "the best network models".

The neural network designing in Statistica Neural Networks software is performed as follows[5]:

- entering input data set and corresponding output signals,

- conducting experiments with selected network architectures and saving the configuration of minimum validation set error,

- when satisfactory error value is not achieved by the network, attempt to add new neurons to the hidden layer or to add another hidden layer must be done,

- when the network is over learned, some hidden neurons must be deleted.

In order to perform an independent check of learning algorithm progress, specified number of training cases is selected from the learning set, thus creating the validation set, excluded from the learning process. The root mean square (RMS) value of the error, determined separately for individual data subsets, is a parameter describing the learning process quality: 


$$
R M S=\sqrt{\frac{\sum_{i=1}^{N}\left(z_{i}-y_{i}\right)^{2}}{N}}
$$

where: $\mathrm{N}$ - number of learning set vectors, $\mathrm{y}_{\mathrm{i}}-$ output neuron signal for ith reference, $\mathrm{z}_{\mathrm{i}}-$ expected output neuron signal for ith reference

The average network response error, determined based on the validation set, enables assessment of network response quality and is also a comparative parameters for analyzed solutions. The moment, where validation set RMS error value stops decreasing, is often accepted as criterion of learning process end. Once the critical point in the learning process is exceeded, i.e. when the learning error value drops and simultaneously the validation error value is steady or starts to increase, further process leads to network over learn, i.e. to excessive match of responses to learning references and lack of learning result generalization capability. During researches concerning capability of ANN application to forecast demand level in trading company, first the regression model for examined selected articles groups has been created. Then the neural network capability to predict the sales value of selected articles has been checked, using the training set with results of determine the value of sales of selected items.

\section{REGRESSION MODEL STRUCTURE AND ANALYSIS}

Demonstration of the applicability of artificial neural networks to predict the demand made on the example of a commercial company - warehouse that sells office supplies. The company, in order to ensure continuity of supply to its customers with its own magazine. The study considered the selected article for known historical sales data. In order to analyze the regression model, the multilayer perceptron, learned based on the backward error propagation algorithm, has been used. In the learning process the data set with variable quantities and corresponding the value of sales has been used. As the networks input signals, the following variable set has been selected:

- $\mathrm{x}_{1}$ - the value of sales of product in a given month

- $\mathrm{x}_{2}$ - the value of sales of product in the group A according to the classification of $\mathrm{ABC}$ in a given month

- $\mathrm{x}_{3}$ - sales value for all products in a given month

- $\mathrm{x}_{4}$ - sales value of produkt at time $\mathrm{t}$

The signal, that is expected on the output, is a sales value of produkt at time t. The automatic network designer from the ST Neural Networks package has determined "the best network" set based on given data set. As prediction models, the networks with three neurons in the input layer and one neuron in the output layer have been used. The hidden layer of neural network for modeling of the sales value of the selected article had 12 hidden neurons (Figure 1). 10\% of randomly selected cases has been separated out of all learning pairs (input signals and corresponding output signals), and then included them in the validation set. 
Fig.1. The neural network architecture for regression model

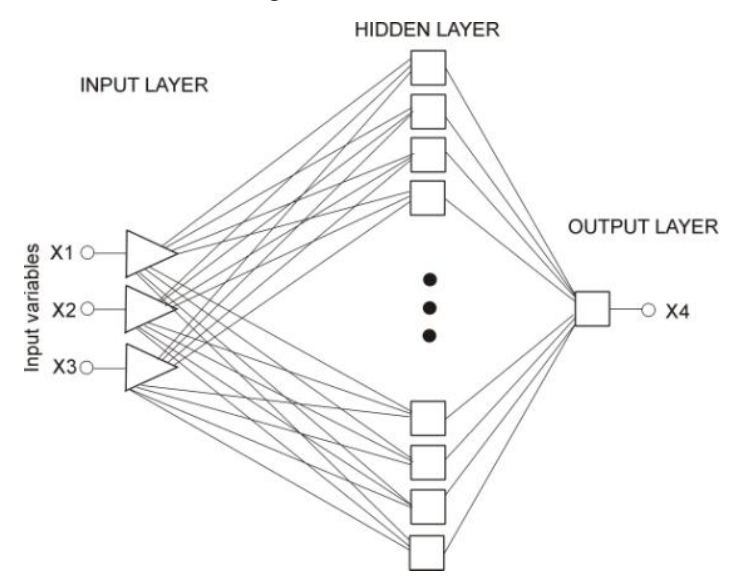

The value of learning coefficient has been assumed as 0.1 for all network architectures. Application of a small learning coefficient value extends the computation duration, but simultaneously enables precise "steps" on the error surface in order to achieve the minimum value. The learning process has been made inert by application of momentum unit of 0.3 .

The learning process duration was about 160 epochs. When assessing the regression model note the error standard deviation ratio and $\mathrm{R}^{2}$ Pearson correlation coefficient between network output values and actual values. For very good model, the error standard deviation ratio is lower than 0.1. High value of $\mathrm{R}^{2}$ Pearson correlation coefficient (0.98) and low error standard deviation ratio of learning set (0.12) speak well for good approximation properties of neural network. This is also reflected in good matching of network predictions and experimental data presented by the learning set (Figure 2).

Fig. 2. Comparison of historical data sales value of article in sales value defined by the neural network (for example ballpen)

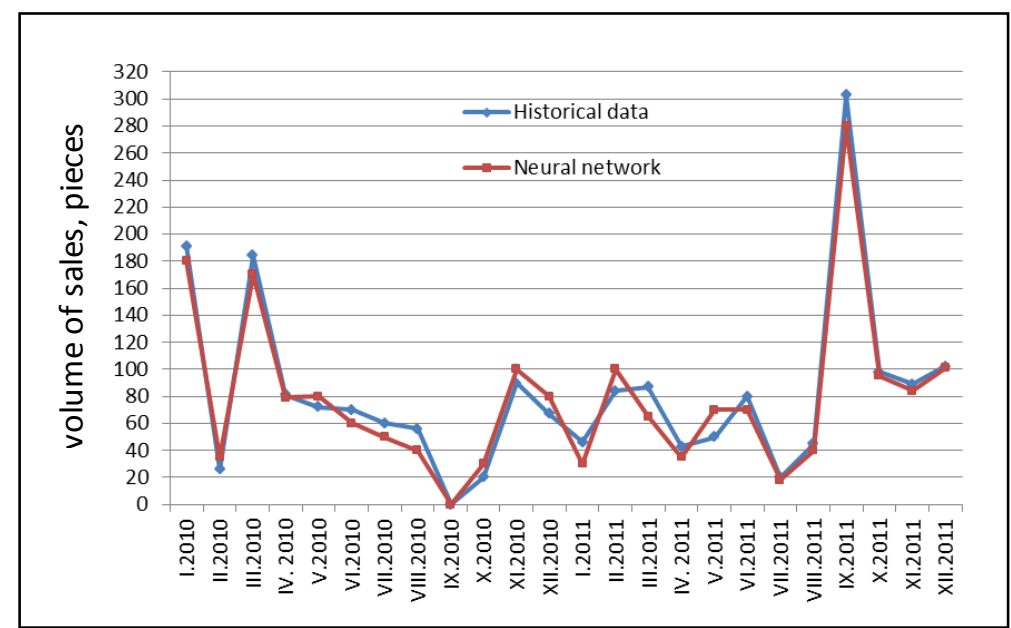




\section{PROGNOSTIC MODEL STRUCTURE AND ANALYSIS}

In order to check the neural network capability to predict-sales value of article, the training set with results of sales value of regression model has been used. The conformity of network output values has been tested based on the results of sales volume which were absent in the training set. The values of tested signals have been within the range of signals used for network learning. In order to validate the convergence of training algorithm additionally to the learning set, the validation set with $10 \%$ of training vectors has been randomly selected. Network training has been conducted for "the best" network set, created by the Intelligent Problem Solver module and containing three in the input layer and, one neuron in the output layer and eight neurons in the hidden layer. The network structure as created by the automatic designer is presented on Figure 3.

Fig. 3. The neural network architecture for prognostic model

$$
\text { Hidden Layer }
$$

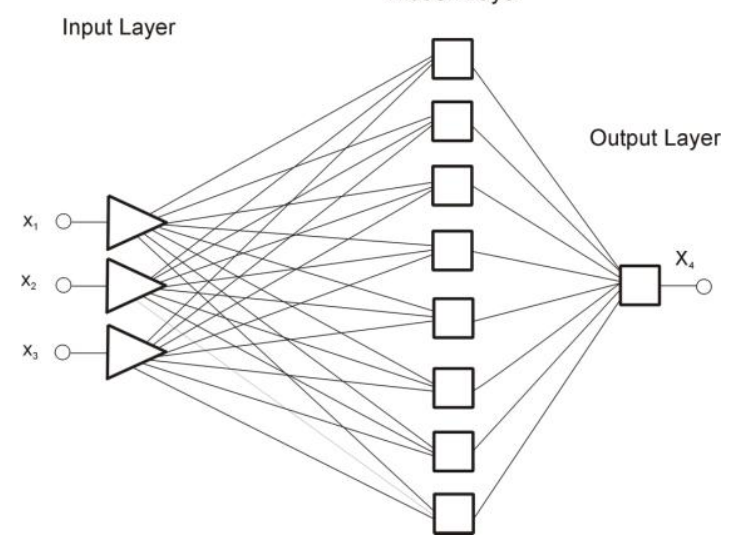

The learning process with the backward error propagation algorithm has been aborted, where no further RMS error value decrease for validation set has been observed after about 400 epochs. The proof of satisfactory prediction quality is achieved low value of RMS error and relatively high value of $\mathrm{R}^{2}$ Pearson correlation for test set $(0.83)$. The correlation coefficient value is a reliable metrics to determine ANN quality. The achieved results may be improved on the way of expanding the learning set by conducting the take into account sales value of article extended period of time. Accounting for additional data in the neural model may be achieved by additional neural network learning.

The neural network may extrapolate the created function out the learning data, but the farther of the known range we are, the lower the chance that the function changes no its characteristics.

\section{CONCLUSIONS}

Structure of the assortment, frequency of delivery, lead time contracts, conditions of storage, organization and structure of distribution channels and the type of use (demand) - these factors influence the choice appropriate methods of inventory control. Based on the results of the simulation model was built made it can be concluded that artificial neural networks are 
very important in predicting economic phenomena and usually give better results than classical methods.

\section{REFERENCES}

[1] Jurczyk K., Zastosowanie sztucznych sieci neuronowych jako narzędzia wspomagającego zarządzanie zapasami i planowanie popytu na przykładzie przedsiębiorstwa dystrybucyjnego, Logistyka 2, 2011

[2] Korzeń Z., Logistyczne systemy transportu bliskiego i magazynowania, Tom II, Biblioteka Logistyka, ILiM, Poznań 1999.

[3] Kudelska I., Zastosowanie sztucznych sieci neuronowych w obszarze logistyki, Logistyka 2, 2008

[4] Mantura W. (red.), Marketing przedsiębiorstw przemysłowych, Wydawnictwo Politechniki Poznańskiej, Poznań 2000.

[5] Statistica Neural Network, Addendum for version 4, Statsoft, Tulsa 1999.

[6] Tadeusiewicz R., Sieci neuronowe, Akad. Oficyna Wydawnicza RM, Warszawa, 1993

[7] Tadeusiewicz R, Sieci neuronowe, WNT, Warszawa, 1998.

\section{MOŻLIWOŚĆ ZASTOSOWANIA SZTUCZNYCH SIECI NEURONOWYCH DO WSPOMAGANIA GOSPODAROWANIA ZAPASAMI}

W artykule dokonano analizy możliwości wykorzystania sztucznych sieci neuronowych do prognozowania poziomu popytu w firmie handlowej. Celem badań było stworzenie i przeprowadzenie analizy regresji oraz utworzenie prognostycznych modeli SSN przy użyciu oprogramowania Statistica Neural Networks. Wyniki modeli neuronowych zostały zweryfikowane z danymi historycznymi wielkości sprzedaży. Uzyskane wyniki potwierdziły możliwość zastosowania modelu SSN jako skutecznego narzędzia do prognozowania poziomu popytu w przedsiębiorstwie handlowym.

DOI: $10.7862 /$ rz.2012.zim.3 